\title{
Racism as 'Reasonableness': Philosophy for Children and The Gated Community of Inquiry
}

Darren Chetty

University College London Institute of Education

\begin{abstract}
In this paper, I argue that the notion of 'reasonableness' that is, for many, at the heart of the Philosophy for Children approach particularly and education for democratic citizenship more broadly, is constituted within the epistemology of 'white ignorance' (Mills 2007) and operates in such a way that it is unlikely to transgress the boundaries of white ignorance so as to view it from without. Drawing on scholarship in critical legal studies and social epistemology, I highlight how notions of reasonableness often include consensus, 'racialised common sense' (Shotwell 2011) and the 'typical' view. In addition the promotion of particular dispositions on the grounds of 'reasonableness' both promotes stability and limits how one may think otherwise. Thus, Philosophy for Children practices that fail to historicise, examine and challenge prevailing notions of reasonableness establish an epistemically 'gated' community of inquiry.
\end{abstract}

\section{Introduction}

In her article in this special issue, Zara Bain notes,

Educating for social justice requires educating in ways that are socially just insofar as we do all that is within our power to ensure that our pedagogy actively works against reproducing the epistemological systems that foster ignorance as a route to racial injustice. (Bain 2018)

In this paper, I argue that the notion of 'reasonableness' that is, for many, at the heart of the Philosophy for Children (P4C) approach particularly and education for democratic citizenship more broadly, is constituted within the epistemology of 'white ignorance' (Mills 2007) and operates in such a way that it is unlikely to transgress the boundaries of white ignorance so as to view it from without. Thus, Philosophy for Children practices that fail to historicise, examine and challenge prevailing notions of reasonableness establish an epistemically 'gated' community of inquiry.

Specifically, I will argue that whilst racism is often assumed to be the preserve of unreasonable individuals, an understanding of the world informed by Charles Mills' The Racial Contract permits us to see that reasonableness might be conceived as both structured by 'white ignorance' produced by 'the racial contract' and as a tool for maintaining 'white ignorance' by rendering actions intended to disrupt and dismantle white supremacy as 'unreasonable', whilst posing as a conceptual and philosophical norm that sits 'outside of ideology'. In 
order to begin to do this I will first offer a brief overview of the notion of 'reasonableness' as discussed in P4C scholarship, before turning to critical legal studies and social epistemology. I will then explore the ways in which some of the assumptions reflected in these debates are echoed in the practice of the community of inquiry, as an example of a pedagogical approach, P4C, explicitly committed to using philosophy to further the values associated with life in democratic, pluralistic societies.

\section{Reasonableness as an educational aim}

I wish to situate this discussion within a broad consensus in educational philosophy, theory and policy, whereby the notion of 'reasonableness' is viewed as an important educational aim and value. This sometimes appears as part of a defence of the need for schools in liberal societies to cultivate civic virtues (see e.g. Callan, 1997) as part of a defence of the importance of critical thinking, or as an element of democratic education. In this paper I will focus on the way in which 'reasonableness' has been developed and defended by scholars arguing for the value of teaching philosophy in schools within the 'Philosophy for Children' or $\mathrm{P} 4 \mathrm{C}$ tradition as an example of an educational practice committed to the value of democracy and the role of philosophy in nurturing and sustaining democratic institutions and values. While this paper will, I hope, be of particular interest to practitioners and scholars of Philosophy for Children, it should also be relevant to those with an interest in education for democracy.

In earlier work, I have focused on issues to do with the choice of resources within P4C practice, especially with young children. (See Chetty, 2014) I argued that the popularity of certain books amongst P4C practitioners as useful sources for enquiring philosophically about racism lent some weight to claiming that the idealised community of inquiry - a truly egalitarian space, where the path of inquiry is not blocked and where all assumptions are examined - - might actually sometimes be operating as a 'Gated Community of Inquiry'. I drew on work on gated communities to explore how this spatial metaphor can be a fruitful way of thinking about how race and racism is dealt with in educational practices such as P4C, where, as Joanna Haynes and Karin Murris write, 'Race and racism often crop up as problematic "no- go" areas'. (Haynes and Murris 2011, p.296). As Atkinson and Flint point out, concerns about safety and security in gated communities enable 'social distance to be maintained' (Atkinson and Flint 2004, p. 875). In such a social climate the unfamiliar is viewed with suspicion and as a potential intruder whose presence is illegitimate. Thus the gated community can, they argue, be viewed as a 'cognitive shelter'.

As well as the materials selected as starting points for philosophical inquiry, I have also explored in other writing (see Chetty and Suissa, 2016), how a sense of discomfort, particularly the discomfort of $\mathrm{P} 4 \mathrm{C}$ practitioners racialised as white, may contribute to the philosophical consideration of racism being pushed to the 
margins or even beyond the intellectual boundaries of the community of inquiry.

In what follows, I build on some of this earlier work, as well as on the work of theorists working within the field of critical philosophy of race and social justice education (see for example, Leonardo 2009, DiAngelo 2011, Boler and Zembylas 2003, Applebaum, 2010) in order to explore the way that reasonableness itself is constituted and understood and how this can limit the possibilities for discussing and addressing race and racism within educational practices that see philosophical thinking as vital to education, and particularly to education for democracy.

It is increasingly difficult to speak of 'Philosophy for Children' as if it is a uniform set of principles and practices. In their Editorial for the 2011 special issue of the Journal of Philosophy of Education entitled 'Philosophy for Children in Transition', Nancy Vansieleghem and David Kennedy explore the various different developments within the broad field of philosophy for and with children 'after Lipman', noting that these multiple views yield significant implications 'as a discourse, a methodology, a philosophical enterprise, and a form of biopolitical production' (Vansieleghem and Kennedy 2011, pp. 179-180)

Whilst the philosophical novels written by Matthew Lipman are still widely used in many countries, in others they are rarely if ever, seen; rather picturebooks, retellings of myths, films, poetry and other works of art are used as starting points for philosophical inquiry. The extent to which teachers work with questions created by students varies - some $\mathrm{P} 4 \mathrm{C}$ advocates regard this as central to their practice, others suggest supplying students with a philosophical question can be a more philosophically productive approach, at least in the early stages of building a 'community of inquiry' '. Lipman's original P4C programme was clearly indebted to John Dewey and the American pragmatists. Subsequent P4C scholars have drawn upon analytic and continental philosophers and on a growing range of theoretical perspectives. However, whilst some scholars of $\mathrm{P} 4 \mathrm{C}$ give 'reasonableness' less attention in their work it remains significant in current P4C scholarship, and is discussed in three chapters of the recent Routledge International Handbook of Philosophy for Children (2017).

As previously mentioned, Matthew Lipman, who began his work on the original Philosophy for Children programme in the late 1960s, saw a very close relationship between reasonableness and critical thinking, citizenship education and democracy, arguing that 'Critical thinking improves reasonableness, and democracy requires reasonable citizens so critical thinking is a necessary means if our goal is a democratic society.'(Lipman 1991, p.244). In a slightly different, and even stronger, formulation, he states: 'I take it that in a democratic society there is

1 'A group of people used to thinking together with a view to increasing their understanding and appreciation of the world around them and each other' (SAPERE 2010, p. 15). 
a maximum premium on the cultivation of reasonableness. The goal of education should therefore be the development of reasonable individuals.' (Lipman 1991, p.64).

Both Tim Sprod and Michael Pritchard add moral education to the list of educational goals for which 'reasonableness' is central. In his highly influential work Reasonable Children: Moral Education and Moral Learning, Pritchard claims that reasonableness is educationally desirable, though it 'is rare even in adults' and is 'not an all-or-nothing concept' (Pritchard 1996, p.ix). As Sprod notes, despite the book's title, Pritchard avoids offering a definition of 'reasonableness', preferring instead to offer what he terms a 'a rough demarcation' (Sprod 2001, p.13). This decision by Pritchard is far from atypical amongst scholarship related to $\mathrm{P} 4 \mathrm{C}$, leading Renia Gasparatou to conclude that 'The ideal of reasonableness seems to provide some common ground, yet the way $\mathrm{P} 4 \mathrm{C}$ theorists characterize reasonableness can be rather vague...' (Gasparatou 2017, p.105). A concept that is at once so important and so nebulous is deserving of closer attention.

Splitter and Sharp view reasonableness as an aspect of rationality but claim that it goes beyond it. 'As an educational ideal, reasonableness goes beyond rationality which is all too-too-often rigid, exclusively deductive, ahistorical and uncreative' (Splitter and Sharp 1995, p.6). In contrast to rationality, 'reasonableness' is seen by Lipman as being comprised of critical and creative thinking, where the 'twin pillars of critical thinking are reasoning and judgment' (Lipman 1991, p.65).

The suggestion that 'reasonableness' is, unlike rationality, not ahistorical is in keeping with some of Lipman's discussion, although this too seems vague at times. For example, Lipman writes that, '[r] easonableness certainly does not exclude cultural literacy, but neither does it specify such literacy in terms of a particular set of contents.' (Lipman 1991, p.65) whilst noting somewhat ambiguously that ' $[\mathrm{w}] \mathrm{e}$ are rapidly moving toward a multicultural world'. Lipman does not discuss what he means by this, nor indeed the history that might have lead us to conceive of our world as monocultural. Elsewhere, Lipman acknowledges criticism of his desired aim for education to produce 'reasonable, judicious and creative individuals'; namely, that it 'emphasizes method at the expense of content' but sees such criticism as mistaken. Rather, he argues,

It is not unusual to find people who are learned but reason poorly and lack judgment. But I cannot imagine anyone being reasonable without acquiring the amount of content a reasonable person ought to have. If knowing too little is injudicious, then surely that is something a judicious person will endeavour to avoid. (Lipman 1991, p. 92)

Lipman appears to envisage that a child who has an education aimed at cultivating reasonableness will 'endeavour to avoid' lacking the necessary knowledge. Given that this quote appears in a section where Lipman argues that schools should 
prioritise cultivating higher-order thinking, it is not clear exactly what knowledge Lipman thinks should be on the curriculum. This may go some way to explaining why whilst he includes knowledge as an element of reasonableness, subsequent P4C scholarship has not tended to explore the relationship between knowledge, the school curriculum and reasonableness. The element of this relationship that I focus on here is the sense in which pedagogical spaces conceived as communities of inquiry may reflect and reproduce the kind of 'knowledge' that can be better understood as a form of ignorance which, as Charles Mills argues, serves an ideological function. As Mills' analysis of white supremacy as a racialised political system of domination shows, the maintenance of this system involves an epistemological contract that establishes 'norms and procedures' for determining what counts as 'moral and factual knowledge of the world' (see Mills, 1997, p. 17; Bain, in this issue.)

The distinction between reasonableness and rationality is perhaps also in need of further attention. Terri Field, in an article that is cautiously optimistic about the potential of $\mathrm{P} 4 \mathrm{C}$, raises questions as to whether Philosophy for Children's advocacy of reasonableness will allow for voices that have been excluded by reason or whether Lipman's P4C project, informed as it is by American pragmatism, is subject to at least some of the same criticisms as those made by feminist philosophers about reason. (Field 1995)

Indeed, whilst Lipman and others have argued that reasonableness is complex and mulitilayered, the vagueness of what precisely reasonableness entails increases the possibility of it being reduced to proceduralism. Thus, the SAPERE Handbook deals with the complexity of reasonableness by advising teachers working with students, '... to reflect on the very idea of reasonableness and on what counts as good reasoning.' (SAPERE 2010, p.23). The Handbook does not give teachers a clear indication of what is meant by reasonableness. At the same time it offers some suggestions/guidelines for ground rules for developing a community of inquiry. These include 'encouraging positive body language, such as eye contact and smiling' and considering the use of 'time out' or 'extra thinking time' if 'someone breaks the rules'. Given the educational aim of cultivating reasonableness through the community of inquiry, these rules and sanctions can presumably be viewed as both reasonable and likely to foster reasonableness.

\section{The social nature of reasonableness}

Whilst acknowledging the literature that discusses 'reasonableness' as multilayered, my twenty-five years of involvement with Philosophy for Children as a trainee, practitioner and trainer has lead me to believe that the two aspects of reasonableness most prevalent in $\mathrm{P} 4 \mathrm{C}$ practice and scholarship in the $\mathrm{UK}$ and mostly likely beyond are as follows: 1) reasonableness is constituted and understood through dialogic inquiry in a community of inquiry that is 2) governed by imposed or negotiated ground rules which are intended to be reasonable and foster reasonableness. 
The role of philosophical dialogue or 'the experience of trying to reason together, as a community' (Lipman 1992, p.21) in cultivating reasonableness is a consistent theme in P4C literature, with Splitter and Sharp viewing reasonableness as 'primarily a social disposition'. (Splitter and Sharp 1995, p.6). Most recently Caralho and Medonça put this in the strongest terms when they claim that, it is not possible to educate for reasonableness without educating persons to think (and feel, and act) for themselves through an ethical experience of dialogue with others.' Carvalho and Mendonça 2017, p.128)

Before discussing how discussions between children in a classroom might foster reasonableness, Pritchard briefly discusses how some committees might be good illustrations of reasonableness - where group deliberation might inform social policies - and considers how committees may ensure that they offer reasonable recommendations. Many of his suggestions relate to openness to reasons, willingness to compromise without compromising personal integrity, and dispositions conducive to dialogue. However he also acknowledges that '[r]epresentative membership can be expected to contribute to the reasonableness of a committee's recommendations' (Pritchard 1996, p.11). This consideration for who is (and is not) present within a deliberative setting, and the extent to which this may affect the constitution of reasonableness, is a further area of $\mathrm{P} 4 \mathrm{C}$ scholarship which, I contend, has received insufficient attention. For in the case of classroom deliberative dialogue we are faced with a challenge concerning representativeness. A legacy of segregated housing, whether through racial laws (in the US or South Africa for example) or house prices makes it rare to find a classroom where the students are representative of the nation in which they are located with regards to race and class. There is a greater likelihood that the students will be representative of the immediate locality (notwithstanding the existence of private schools and, in the UK, faith schools), but it is questionable as to whether that local population has itself been shaped through reasonable circumstances. Given that deliberative dialogue is seen by P4C scholars as having a central role in the development of reasonableness in children, the question of representativeness and the non-ideal conditions that impede it are important for considering the detrimental impact this may have on the views and testimony that students will encounter in the community of inquiry.

A racially representative classroom is not the norm in the UK (where I live and teach), in the USA (where P4C originated) or in South Africa (where I retain family connections and where a growing amount of $\mathrm{P} 4 \mathrm{C}$ work is happening). Nor indeed is it the norm at $\mathrm{P} 4 \mathrm{C}$ related conferences. Indeed at the most recent ICPIC $^{2}$ Conference, one of the key-note speakers noted - not entirely accurately - that there were no Black people present. If representativeness is important for reasonable deliberation, educators faced with unrepresentative classrooms and

2 ICPIC is the International Council for Philosophical Inquiry with Children. Conferences are held biennially. In 2017 the conference was held in Madrid. 
educational spaces presumably need to take active steps to bring in perspectives that are insufficiently represented, particularly when their under-representation may be related to historical oppression and marginalisation.

The teacher's role in the community of inquiry is described by Lipman's successor at the Institute for the Advancement of Philosophy for Children (IAPC), Maughn Gregory, as to 'shore up the fairness and reasonableness of the discussion.' (Gregory 2005, p.2). This is not a straightforward task. While the question of what notion of reasonableness teachers are most likely working with is an empirical question beyond the scope of this paper, it is worthy of some research attention, not least because, as Lipman, Sharp and Oscanyan put it, 'the teacher is the one who has to make the judgment as to whether a particular personal account should be capitalized upon or squelched' (1980, p.92).My observation, from working with teachers, is that they will often take their cue from everyday language usage of 'reasonableness', which often reflects how the term is used in policy and the law. For this reason, in this next section I focus on discussion of reasonableness and race in critical legal studies.

\section{Reasonableness and the Law}

In Reasonableness, Racism and The Articulation of Bias, a study of the use of reasonableness in criminal law, Nicola Y. Wright, uses the term 'reasonable man' to mean 'the anthropormorphism of the law's devotion to "reasonableness and rationality", as well as its claim of "neutrality" and "objectivity" (Wright 1996, p.2). In order to test whether a person has acted as a reasonable person would, it has for some time been common in UK courts to refer to 'The man on The Clapham Omnibus'. This derives from a time when Clapham was seen as part of the suburban commuter belt of London. The man in question is said to be reasonably intelligent and educated. Jody Armour finds similar use of personifications in US law: "the ordinary prudent man," "the average man," "the man in the street", and the "man who takes the magazines at home, and in the evenings pushes the lawn mower in his shirt sleeves." (Armour 1997, p.22). The last of these three mostly clearly implies, like the Victorian commuter to London, a person who is gendered, classed and raced. In Negrophobia and Reasonable Racism, Armour highlights court cases where lawyers representing white defendants who have shot a black person argue that they did so out of reasonable fear of attack and in so doing 'exploit the racial fears of jurors in asserting the reasonableness of their fear of supposed assailants who are Black' (Armour 1997, p.4 ). Armour concludes, 'Certainly the reasonableness standard, in its classic formulation (e.g., the "average man"), privileges the perspective of the majority'. He posits the idea of the 'reasonable racist'. By this he means someone who holds racist beliefs but who holds that s/he can be excused for them because they can be shown to be typical, majority views and 'blame is reserved for the (statistically) deviant' (Kelman 1991 cited in Armour 1997, p.19). Armour summarises his argument thus, 
The legal definition of reasonableness is uniquely insidious in that it takes the merely typical and contingent and presents it as truth and morality, objectively construed. For example, according to legal usage, the 'objective' standard of reasonableness encompasses those beliefs and attitudes that are shared by most people. (Armour 1997, p.26)

Armour argues that the role of the courts is often taken to be to observe rather than define the attributes of the reasonable man. Whilst we have already seen that Philosophy for Children scholarship advocates a more nuanced 'multilayered' sense of reasonableness than that of 'the reasonable man', it is still a useful exercise for educators to identify elements of the practice that might be implicitly working with this understanding of reasonableness. A common implicit argument in $\mathrm{P} 4 \mathrm{C}$ scholarship is that in order to address continuing racism it is the cultivation of reasonableness that is required. However, I suggest, reasonableness as commonly understood in the law may not only be shaped by a racist past but help secure a racist present.

\section{Racialised Common Sense}

This critical perspective on the association between the notion of reasonableness, the claim to neutrality, and the perspective of the majority suggests the educational significance, when it comes to cultivating genuinely democratic dialogical deliberation, of attending not just to the question of who is present in the community of inquiry, but to the underlying relationships of domination and their historical roots. For even if we were to find a classroom where the make-up of students is representative of the nation in which they live (leaving aside for now questions of why the historically contingent and often unreasonable boundaries of the nation should be our measure), we still find ourselves in a situation, the representative constitution of which may mask the relationships of domination that characterise the society in question. In this sense, such a classroom may be seen as a non-ideal situation, within which the avowed educational starting-point of reasonableness and neutrality serve as an ideal analogous to the role of ideal theory in Mills' criticism of liberal theory, where, as he notes, 'Obviously such a starting point crucially handicaps any realistic social epistemology, since in effect it turns things upside down. Sexism and racism, patriarchy and white supremacy, have not been the exception but the norm.' (Mills 2007, p.17).

It may be objected here that in the context of $\mathrm{P} 4 \mathrm{C}$, given its concern with relationships amongst reasoners, the suggestion that majority perspectives will be privileged in philosophical enquiries is overstated. It is important to note that whilst certain perspectives might be in the majority in a community of inquiry, the emphasis given to reason in $\mathrm{P} 4 \mathrm{C}$ enables a minority perspective to be heard, considered and judged persuasive by a majority - if it is adjudged to be the most reasonable perspective. However, Meira Levinson sounds a note of caution about 
this, when she observes that in multiracial classrooms, 'differences of opinion and priorities in part reflect differences in life experience that lead members of different racial/ethnic groups to "read" the world in different ways. The problem, however, is that this often results in majority group members judging minority perspectives as being totally irrational, as well as unreasonable.' (Levinson 2012, pp.75-76)

Furthermore, as the analysis of white ignorance reveals, the prevailing notion of reasonableness can involve not just a cognitive model or a set of procedural norms, but also an accepted set of behaviours. Thus a standard of reasonableness might serve to limit the extent to which a person from, say, a racially minoritised perspective can argue, challenge and disagree with what is taken to be 'reasonable' with regard to racism. In further exploring how such processes may play out in pedagogical situations, it is helpful to consider what Alexis Shotwell terms 'racialized common sense' (Shotwell 2011).

As Shotwell explains, in a passage clearly evoking Mills' notion of 'white ignorance',

Common sense is formed at the fulcrum of what we care to know, and what we cannot know under current conditions, what we refuse to know, and what we would have to transform ourselves in order to know. When we have commonsense knowledge, we do seem to know something, frequently even in a strong sense of the term 'know' - but this knowledge is frequently a product of and productive of inequitable social worlds. As a norm, an epistemology of ignorance perpetuates the common sense it describes. (Shotwell 2011, p.37)

An example of the way in which such 'racialized common sense' can serve to block discussions of racism on the part of people from racialised minorities can be glimpsed in Leonardo's observation that 'Anyone who has performed a radical racial analysis has faced...a scenario where the messenger is dismissed because the message produces psychological dissonance between a white subject's desire for racial justice and her inability to accept radical change.'

(Leonardo 2009, p.82)

On the face of it philosophical inquiry should help us to examine 'racialised common sense' assumptions. However, in social contexts structured by the operation of white supremacy as a racialised system of domination involving the epistemic aspects described in Mills' analysis of white ignorance, our guiding notion of 'reasonableness' may itself be infected with racialised common sense. As Shotwell writes, 'The close link between reason, white, and what it is to be human - or the extent to which those three attributes end up being coterminous should give us pause.' (Shotwell 2011, p.61)

In a similar analysis, David Theo Goldberg explores how representations in racial 
discourse 'draw their efficacy from traditions, conventions, institutions, and tacit modes of mutual comprehension' (1993, p. 46). Goldberg frames this underlying stratum as the pre-conceptual plane that underlies and shapes modernity's common sense (pp. 38, 43)

What this discussion suggests is that, in the context of attempts at dialogue and deliberation that invoke, explicitly or implicitly, normative notions of reasonableness, there is a danger that reasonableness can imply a prioritisation of stability; a notion that, in turn, may suggest not moving too far from where we are and not looking too closely at how we got here. A crucial step in correcting this potential bias is insisting on the importance, especially in an educational context, of historical perspectives. Yet, as I discuss in the next section, it is this perspective that is arguably missing from many approaches to philosophical dialogue as a means to cultivating reason and enhancing democracy.

\section{The problem of ahistoric reasonableness}

Marguerite and Michael Rivage-Seul discuss a P4C project implemented in Guatemala in 1987, two years after the election of civilian president Vincio Cerezo, after thirty years of military dictatorship. Whilst they see much that is positive in $\mathrm{P} 4 \mathrm{C}$, they view it as lacking some of the essential qualities for democratic education offered by educators working in the Freirian tradition:

The founding belief seems to be that teaching children to think reasonably, responsibly and philosophically can eventually empower the Guatemalan majority to take advantage of democracy's promises. The implication is that democracy is not being realized because of deficiencies in reasoning on the part of Guatemalan adults. Hope for democracy's full implementation are thus pinned on elementary schoolchildren, who, despite the fact that most attend school for no more than a few years, are to bring reason to Guatemala's political processes in a generation or so. (Rivage-Seul and Rivage-Seul 1994, p.45)

They go on to make the more disturbing criticism that

Indeed, if we consider the structured silences in the P4C program we see how pretensions to uncommitted objectivity actually help the Guatemalan government establish locally and internationally its claim that it is in fact democratic. Moreover, regardless of whether one agrees or disagrees with the claim, accepting its practical validity and leaving it unquestioned represents a political option on the part of $P 4 C$ in support of the Cerezo government and against the dissenting constituency represented by Bermudez and by the Guatemalan Army of the Poor. Acceptance effectively comprises an option in support of the Guatemalan ruling classes. (RivageSeul, M. and Rivage-Seul, M., 1994, p. 57; my emphasis). 
Marguerite and Michael Rivage-Seul argue that Lipman's P4C program does not engage with history. 'While laudably characterized by dialogue, such pedagogy ignores the historicity of what is known' (Rivage-Seul \& Rivage-Seul 1994, p.48). It is perhaps not surprising that significant criticisms of Lipmans's P4C program have tended to come from Latin America, and have often placed P4C in the context of US 'interventions' - whether military, political or educational - in the region. While these criticisms highlight the hypocrisies and contradictions in the US self-image as a democracy, in the context of the present discussion I want to focus on the way in which they reveal the ways in which white ignorance may be operating to reflect and reinscribe relations of domination, whether at a global or a local level. In this sense, Rivage-Seuls' analysis has affinities with Mills' discussion of the 'management of memory', and with the related analysis of 'technologies of colonization' developed by De Lissovoy.

Reasonableness in education is explored by Noah De Lissovoy with regard to race as follows:

In this way, the reasonable as an ideological formation in education does not simply distort a more authentic reason, but rather serves as a technology of colonization. It is not simply that elites operate according to a rationality that privileges their own class-racial interests, but rather that the violation of communities of color becomes the positive content of good sense in White politics and policy, according to the Manichean logic of colonial society outlined by Fanon (1963)... Activists for equity in education who seek to intervene in official policy-making circles need to realize that they confront not only political headwinds, but also a form of rationality that depends on the abjection of the poor, Black and Brown as the condition of its own dubious virtue. (De Lissovoy 2016, p.353)

Furthermore, the criticisms of $\mathrm{P} 4 \mathrm{C}$ as a practice that is guilty of 'ahistoricity', whether or not they can be fairly made of Mathew Lipman's work, are echoed in critical discussions of the discipline of philosophy itself. As Carlos Sanchez puts it, many professional philosophers believe that 'if a thinking situates itself, embodies itself, or historicizes itself, then it is not profound, and worse, not philosophy' (Sanchez 2011, p. 40, cited in Dotson 2012, p. 14).

Much of Charles Mills's work is devoted to showing how philosophers have dehistoricized race. In The Racial Contract Charles Mills points out that the fact that the discussion of race and racism is so often absent from western philosophy might lead one to think that race and racism have been marginal to the history of the West. But in actuality, we need to understand how the 'exclusion or marginalization of race and its typically sanitized, whitewashed, and amnesiac account of European imperialism and settlement, is deeply flawed and misleading.' Reflecting on some of the explicit expressions of racist and colonial attitudes in Kant's work, he observes that 'white academic philosophy as an institution has had no interest in researching the implications of, and making 
known to the world this dimension of Kant's work,' Mills (1997, p.71). As a result, when one considers the historical complicity of academic philosophy in obscuring and excluding matters of racialisation from that which is considered to be 'proper' study, it becomes easier to understand the expressions of surprise, bewilderment, and alarm that have arisen from both media commentators and professional philosophers, in response to calls to decolonise philosophy courses at universities in the UK and beyond.

This discussion also has important implications for questions of who is included in the academic philosophy community, and who is excluded from it. In her 2012 paper 'How is this Paper Philosophy?' Kristie Dotson 'answers a call made by Anita Allen to genuinely assess whether the field of philosophy has the capacity to sustain the work of diverse peoples.' (Dotson 2012, p.3). Drawing on Gayle Salamon's 'Justification and Queer Method, or Leaving Philosophy' Dotson argues that academic philosophy privileges a 'culture of justification' where justification is 'making congruent' one's position with acceptable norms (Salamon 2009:226). As Dotson explains,

Typified in the question, 'how is this paper philosophy,' is a presumption of a set of commonly held, univocally relevant, historical precedents that one could and should use to evaluate answers to the question. By relying upon, a presumably, commonly held set of normative, historical precedents, the question of how a given paper is philosophy betrays a value based on performances and/or narratives of legitimation. Legitimation, here, refers to practices and processes aimed at judging whether some belief, practice, and/or process conforms to accepted standards and patterns, i.e. justifying norms. (Dotson 2012, p.5).

I detect a similar attitude and set of assumptions in the words of an established philosophy for children practitioner and writer who responded to one of my earliest attempts to philosophise about race in the community of inquiry with the observation that, though socially significant, race is not philosophically interesting - whereas 'differences is'. I suggest that here we have an example in the community of inquiry of the same problem that Mills highlights, and that can be seen as a specific example of the operation of white ignorance.

It is perhaps not too great a leap to conclude that, according to this person, my thoughts were presumably then not philosophical. What if similar thoughts were expressed by a child in a classroom? The above discussion suggests that in a classroom where children are engaged in a philosophical inquiry structured by norms of 'reasonableness', the constitution of certain contributions as 'unreasonable' may serve to exclude perspectives offered by pupils from racialised minorities, and in so doing, to both mask and perpetuate racialised structures of domination. 
Dotson makes the important point that 'one has to examine closely who has the burden of destabilizing norms any given time and whether this a worthy activity for the targeted populations. Diverse practitioners may disproportionally shoulder it.' (Dotson 2012, p.15)

This burden may go some way to explaining the continuing absence of people of colour at $\mathrm{P} 4 \mathrm{C}$ seminars and conferences. It may also explain why so few philosophers of colour have embraced Philosophy for Children despite the liberatory potential claimed by many of its advocates. But even more than this it should raise questions about who is shouldering the burden for doing the philosophical labour in our classrooms.

Crucially, for our discussion of the operation of philosophical dialogue in $\mathrm{P} 4 \mathrm{C}$ and other educational contexts, De Lissovoy argues that a kind of thinking that would break with reasonableness 'will show up in the first instance as unreasonable.'(2016; p. 346) What might such 'kinds of thinking' look like, and how might we come to see them as pedagogically valuable? In the next section, I explore the possibility that, as part of the necessity of revealing and addressing the historical processes that come to constitute forms of white ignorance, and that therefore may inflect dominant notions of 'reasonableness', disruptions initially perceived as 'unreasonable' may have an educational value.

\section{'Unreasonable' disruptions of Denial/White Ignorance/Reasonableness}

The recent 'Rhodes Must Fall' campaign at Oxford University may be an example of unreasonable public pedagogy. In reality, the campaign's very name is a demand for an 'unreasonable' action - the removal of a statue. This is sufficiently unreasonable behaviour to be newsworthy. Newspaper articles covered the campaign. Think-pieces were produced in broadsheets and online platforms. Many of them focused primarily or exclusively on the 'unreasonableness' of the demand to take down the statue of Cecil Rhodes. Some articles however did not avoid engaging with the campaign's justifications for its demands. Articles detailing Cecil Rhodes' behaviour and writings appeared. So too did articles pointing out that the taking down of statues is not the sole preserve of ISIS, and also exploring how the demand to 'remove' a statue is not equivalent to a simple act of destruction and can express a more complex and nuanced political position. For example, there is a complex history of removing statues celebrating Nazism and Soviet Communism in post-war Europe. In Lithuania and Hungary ${ }^{3}$ there are memorial parks where one can visit the statues to communism that were erected and, after the fall of communism in the country, removed but not destroyed. Implicit in the park is the idea that the statues are worthy of being taken seriously as historical artefacts even as they are not worthy of remaining in place as celebrations of deeply oppressive ideals. Might we say the same of Cecil Rhodes? And if not why not? These are important moral questions, which are best answered

\footnotetext{
${ }^{3}$ See http://grutoparkas.lt/en US/ and http://www.mementopark.hu
} 
with sufficient historical knowledge. These are questions which many of us concerned about social justice and education asked ourselves and each other. These are questions brought into public consciousness by 'unreasonable pedagogy'. The campaign did not succeed in its stated aim to relocate the statue. However Oriel College's backtracking on its offer of a six-month consultation period due to concern that it would lose donors revealed how the preservation of wealth impacts decision-making now as it did in Rhodes' era. ${ }^{4}$ (Telegraph)

The campaigners could have limited their concerns about Oxford University's relationship to racism and colonialism to a 'reasonable' course of action. I speculate that had they done so, the issues would have reached far fewer people and generated less discussion. They might have attempted to educate people only by means of more traditional academic practices, such as running seminars, lectures, writing historically informed papers about Cecil Rhodes, the University's relationship with colonialism, and so on. A series of student-run debates might have been held perhaps even with a number of sympathetic academics in attendance. If the institution was put under great pressure it may have commented on these discussions. It might have pointed out how proud it was that the fine tradition of debate at Oxford was being continued. In other words, without even needing to engage with substantive issues, it could communicate a congratulatory message to students for their conduct - conduct that is in keeping with the norms of the institutions. And given that the institution has historically defined those norms, this message could be read as a self-congratulatory message for the continuation of reasonableness in the institution. However, if this were to have happened, it is unlikely that anyone outside of Oxford University would ever have become aware of the debates taking place. The willingness of donors to threaten to withhold funds and the seemingly crucial role that would play would not have been revealed to the wider public.

As a result we might reflect on how starting in a place that appears at first unreasonable might help us to perceive the historical and social processes that contribute to our conception of reasonableness. Therefore possibilities for coming to know the world - and for challenging white ignorance and its political consequences - might be limited by an emphasis on a procedural notion of reasonableness that forecloses opportunities for inquiry and for knowing.

\section{Conclusion}

Laurence Splitter and Ann Margaret Sharp note, " $[\mathrm{t}]$ he concept of a "reasonable person" lies at the heart of Philosophy for Children and, arguably, of education itself and the ideal of democracy.' (Splitter and Sharp 1995, p.6)

They go on to argue that reasonableness is linked to, but goes beyond, rationality,

4

http://www.telegraph.co.uk/education/universityeducation/12129261/Fina lly-Oriel-College-should-have-stood-up-to-Rhodes-Must-Fall-long-ago.html 
which they view as 'all-to-often rigid, exclusively deductive, ahistorical and uncreative'. As Tim Sprod notes, they argue that reasonableness is 'not just process oriented (requiring sufficient knowledge or content as well)' (Sprod 2001, p.13).

In the above discussion, I have attempted to attend to the process element of reasonableness whilst also making a case for giving knowledge a greater status than the brackets above might imply. I have explored the ways in which the prevailing notions of reasonableness operating within everyday language, within academic philosophy, and within philosophical inquiry in the classroom, reflect layers of complex historical and social meaning. Specifically, I have suggested that reasonableness, so construed, can be understood as constituted by and reinscribing the epistemological features of white ignorance.

If reasonableness is, unlike reason, not ahistoric, then the cultivation of reasonable citizens presumably includes a commitment to the teaching of history. This seems vital to Mills' discussion of 'The Racial Contract', and indeed to much work in the critical philosophy of race. It raises questions then for how P4C practitioners, programmes and theorists engage with history as a subject of study and understand its place in philosophy and the community of inquiry.

Advocates of P4C would then be well served by historicising the movement itself, perhaps, given his influence on Matthew Lipman, beginning with the philosophy of John Dewey.

I think that the great John Dewey never saw white supremacy as a major priority in his wrestling with philosophical and democracy. I think that is sad...you can't really be wrestling with American democracy unless you also come to terms with its legacy rooted in slavery, Jim Crow, and so on. So in that regard I think, despite his greatness and his genius, it is a major silence...(Cornel West 2004, p.226))

The cultural milieu in which deliberation takes place is often one of white supremacy and white ignorance. The school curriculum is an element of this. Dialogical deliberation is thus limited in its scope for examining this milieu given that it is governed by reasonableness. That is not to say it is impossible, but rather that it is highly unlikely.

\section{Acknowledgements:}

I would like to thank Judith Suissa for her editorial guidance and comments on an earlier draft of this paper.

\section{References}


Applebaum, B., 2010. Being White, Being Good: White Complicity, White Moral Responsibility, and Social Justice Pedagogy. Lexington Books.

Armour, J.D. 1997. Negrophobia and Reasonable Racism. New York and London: New York University Press.

Atkinson, R. and Flint, J., 2004. 'Fortress UK? Gated communities, the spatial revolt of the elites and time-space trajectories of segregation'. Housing studies, 19(6), pp.875-892.

Boler, M. and Zembylas, M., 2003. 'Discomforting truths: The emotional terrain of understanding difference'. Pedagogies of difference: Rethinking education for social change, pp.110-136.

Bain, Z. 2018. "Is There Such a Thing as White Ignorance in British Education" Ethics and Education.

Callan, E., 1997. Creating Citizens: Political Education and Liberal Democracy. Clarendon Press.

Costa-Carvalho, M. \& Mendonça, D. 2017 'Thinking as a Community: Reasonableness and Emotions' . In: Gregory, M., Haynes, J., and Murris, K., (eds) The Routledge International Handbook of Philosophy for Children. Abingdon: Routledge.

Chetty, D., 2014. 'The Elephant In The Room: Picturebooks, Philosophy for Children and Racism'. Childhood \& Philosophy, 10(19).

Chetty, D. and Suissa, J., 2016. 'No Go Areas: Racism and Discomfort in the Community of Inquiry'. Gregory, M., Haynes, J., and Murris, K., (eds) The Routledge International Handbook of Philosophy for Children. Abingdon: Routledge.

De Lissovoy, N., 2016. 'Race, Reason and Reasonableness: Toward an “Unreasonable” Pedagogy'. Educational Studies, 52(4), pp.346-362.

DiAngelo, R., 2011. 'White fragility'. The International Journal of Critical Pedagogy, 3(3).

Dotson, K., 2013. 'How is This Paper Philosophy?'. Comparative Philosophy, 3(1), pp.121-121.

Field, T., 1995. 'Philosophy for Children and the Feminist Critique of Reason'. Critical and Creative Thinking, 3(1), pp.9-12. 
Gasparatou, R., 2016. 'Philosophy For/With Children And The Development Of Epistemically Virtuous Agents'. The Routledge International Handbook of Philosophy for Children, p.103.

Goldberg, D.T., 1993. Racist Culture (p. 91). Cambridge, MA: Blackwell Publishers.

Shaughnessy, M.F., 2005. 'An interview with Maughn Gregory: About philosophy, critical thinking and higher-order thinking'. The Korean Journal of Thinking \& Problem Solving, 15(1), pp.115-125.

Gregory, M.R, Haynes, J and Murris, K. 2017. The Routledge International Handbook of Philosophy For Children. London and New York: Routledge.

Haynes, J. and Murris, K., 2011. 'The provocation of an epistemological shift in teacher education through philosophy with children'. Journal of Philosophy of Education, 45(2), pp.285-303.

Kelman, M., 1991. 'Reasonable Evidence of Reasonableness'. Critical Inquiry, 17(4), pp.798-817.

Leonardo, Z., 2004. 'The Color of Supremacy: Beyond the Discourse of "White Privilege"'. Educational Philosophy and Theory, 36(2), pp.137-152.

Leonardo, Z., 2009. Race, Whiteness, and Education. Routledge.

Levinson, M., 2012. No Citizen Left Behind (Vol. 13). Harvard University Press.

Lipman, M. and Sharp, A.M., and Oscanyan, F.S (1980). Philosophy in the Classroom. Philadelphia: Temple University Press.

Lipman, M. 1991. Thinking in Education. New York: Cambridge University Press.

Lipman, M. 2003. Thinking in Education (Second Edition). New York: Cambridge University Press.

Mills, C.W. 1997. The Racial Contract. Ithaca and London: Cornell University Press.

Mills, C.W. 2007 White Ignorance in Sullivan, S. and Tuana, N. eds., Race and Epistemologies of Ignorance. Albany, NY: SUNY Press.

Pateman, C and Mills, C.W. 2007. Contract and Domination. Cambridge: Polity Press. 
Pritchard, M.S. 1996. Reasonable Children: Moral Education and Moral Learning. Lawrence, KS: University Press of Kansas.

Rivage-Seul, M. and Rivage-Seul, M., 1994. 'Critical Thought And Moral Imagination: Peace Education In Freirean Perspective'. In Lankshear, C. and McLaren, P. (Eds) Politics Of Liberation: Paths From Freire. London: Routledge. pp.41-61.

Sánchez, C.A., 2011. 'Philosophy and the Post-Immigrant Fear'. Philosophy in the Contemporary World, 18(1), pp.31-42.

SAPERE (2010) SAPERE Handbook To Accompany Level 1 Course. $3^{\text {rd }}$ Edition. SAPERE

Shotwell, A. 2011. Knowing Otherwise: Race, Gender, and Implicit Understanding. University Park: Pennsylvania: Pennsylvania State University Press.

Splitter, L., \& Sharp, A. M., 1995. Teaching for Better Thinking: The Classroom Community of Enquiry. Melbourne: Acer.

Sprod, T. 2001. Philosophical Discussion in Moral Educations: The Community of Ethical Inquiry. London and New York: Routledge.

Vansieleghem, N and Kennedy, D. 2012. Philosophy for Children in Transition; Problems and Prospects. Oxford: Wiley-Blackwell.

West, C. (2004) 'Afterword: A Conversation Between Cornel West and Bill E. Lawson' in Lawson, B. and Koch, D. F. (eds) Pragmatism and the Problem of Race. Bloomington and Indianapolis: Indiana University Press.

Wright, N.Y., 1996. Reasonableness, Racism and the Articulation of Bias. University of Ottawa (Canada). Unpublished Thesis. 